\title{
A kiss isn't just a kiss
}

Mouth-to-mouth resuscitation.

\begin{abstract}
Steve Carper
On its slowest day, Hong Kong International Airport fed tens of thousands of bodies into the jets bearing the insignia of 60 different airlines. Today, the bodies jostled one another in lines that boiled and roiled and dissolved and reformed as loved ones gave one another parting kisses. Then kissed friends, children, strangers, staff, crew, baggage handlers, taxi drivers and police, who kept threatening them with their clubs. The flu had arrived and they were the first wave out of the infected area.

Flu.
\end{abstract}

In Chinese and English the word jumped at them, from newspaper headlines to the captioning of CNN International and SkyNet to the announcement tickers above every bank of screens. They were heading across the world: direct flights to almost every continent. Thousands would greet them at every airport, braving the clubs of their country's police and armed forces for the wonderful, life-granting prize of all prizes, the other word blazoned across every means of communication in the airport.

Cure.

The first signs of the avian flu strain to be labelled H5LB7 appeared in villages in northern Vietnam in early February. Authorities quickly set up roadblocks and sent in teams to destroy the infected chickens, but rumours of an extraordinarily high percentage of deaths filtered out. It was later revealed that dead birds and dead humans alike were spirited across the border to the National Key Laboratory of Veterinary Biotechnology in Harbin.

As the flu spread across Vietnam into Laos and Guangxi and Guangdong provinces, virologists adapted a technique that had earlier proved useful against the $\mathrm{H} 5 \mathrm{~N} 1$ strain. Unlocking the virus's genome, they cloned segments of its DNA and proceeded to mutate genes and reintroduce them into the genome. By July they had a stable strain of the virus that acted as a viable vaccine.

It was almost too late. Shenzhen Airlines was no longer flying out of Nanning in the affected provinces. Xiamen Airlines, Shanghai Airlines, Sichuan Airlines and both China Eastern and China Southern Airlines had been forced to shut down all but a bare few emergency flights to and from surrounding countries.

“The vaccine works," reported Dr Cao Xiping. "The new virus displays both the haemagglutinin and neuraminidase antigens. We added to those genes a half-dozen others known for their ability to grow inside eggs as a base medium, which we can then refine to capture the vaccine."

"Eggs?" asked the agriculture minister. "How long to grow a billion doses inside eggs?"

Dr Cao gave the number. Too long. Too expensive. Too difficult. Everything was against it. The minister tried to wipe the look of scared horror off his face sufficiently to look angry and threatening, with minimal success.

"We do have another idea," said Dr Zhu Yi. "Naturally, it has never been tested. But it does have the advantage of the quickest and cheapest wide-scale dissemination of the vaccine practicable."

"Let's hear it," the minister said.

He didn't like it. He was against it. He went into a tirade that would have intimidated anyone not as bone-tired and singleminded as the virologists had become after weeks of unending death. The meeting went on for hours. At midnight the minister capitulated. He did not look happy. His expression did not change even after Dr Zhu gave him a long and somewhat sloppy kiss. He wiped his mouth with a napkin left over from the dinner and hurried home to kiss his wife and children.

None of them contracted the flu.

Technicians at the National Key Laboratory started incubating eggs, while virologists mutated more genes on the already mutated virus. Doses of the vaccine were refined at almost the same rate and number as the list of airports, seaports and border checkpoints being sealed off because of the spreading infection.

Meetings at the Ministry of Agriculture grew in similar hypertrophic fashion, as representatives of the ministries of health, science and technology, communications, foreign affairs, state security and national defence joined around ever-larger tables. Their decision went out through all staterun media. Volunteers would gather at the Hong Kong International Airport in one week's time. All travel expenses would be paid. So would their burial expenses if anything went wrong, although that part was whispered to them as they gathered.

The news exploded onto the world to be greeted with an array of emotions as vast as all humanity. The Chinese had perfected a cure for the deadliest strain of flu ever encountered. There was no time to inoculate everyone. A faster mode of transmission was necessary. And the fastest mode of transmission known to mankind was ... mankind.

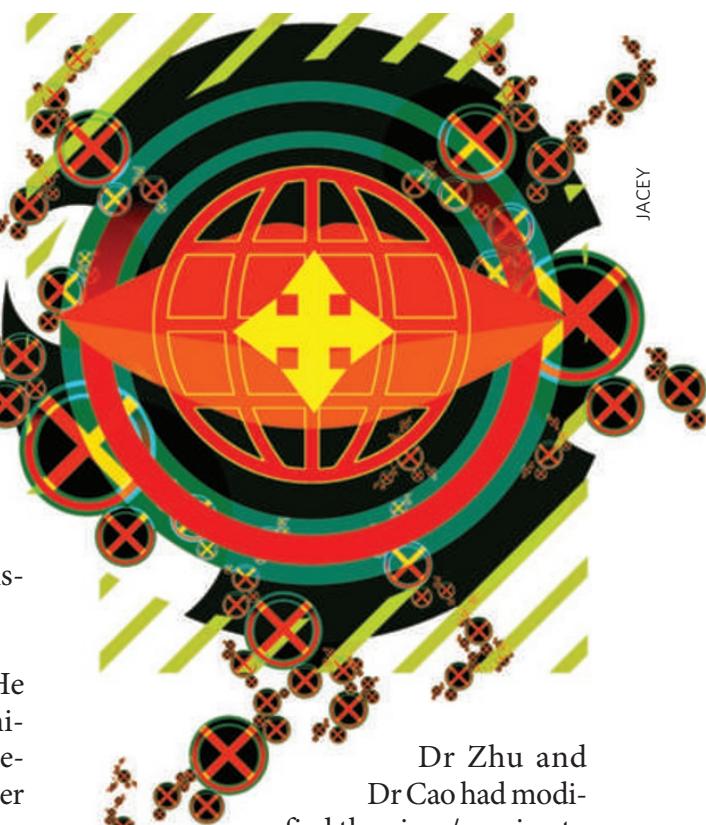

fied the virus/vaccine to be transmissible by humanto-human contact. It lived thrived! - in saliva. Kissing was an exemplary use of the human vector. People met people faster than any other form of contact, short of spraying from aeroplanes. There were technical reasons why that wasn't feasible, but they were lost under the sounds of the explosion as the world learned that to save itself it had to - as the British tabloids headlined over and over - snog.

The first wave funnelled through the newly reopened Hong Kong International Airport on Chek Lap Kok, kissing everyone within reach. They fanned out through the cities of dozens of nations, an exponential force, disinfecting dozens in each. Men kissed men, women kissed women, all kissed children and babies, and those who fought the contact were, it is accurate to say, sometimes kissed against their will. Few of those who successfully resisted died, but that was because by then so few successful carriers surrounded them.

The H5LB7 flu killed several million people in south Asia and smaller numbers elsewhere. About a billion people who might otherwise have died did not.

Some of them actually looked forward to the next year's flu season.

Steve Carper's collection of fantasy and science-fiction short stories is Tyrannosaur Faire. He is editing the next edition of the SFWA Handbook and is a columnist for the SFWA Bulletin. Join the discussion of Futures in Nature at http://tinyurl.com/kkh3kt 